David Clapham: The Meaning of Housing - A Pathway Approach.

Bristol: Policy Press, 2005 (286 sider)

En af sociologiens grundlæggende konflikter handler om forholdet mellem aktør og struktur. By- og boligforskningen indskriver sig også i denne konflikt, og det kommer til udtryk ved, at der enten udføres endeløse statistiske analyser af boligområdedata med det formål at afdække strukturelle ændringer eller der gennemføres kvalitative fortællinger om hverdagslivet i by- og boligområder. Hvor der inden for den sociologiske tradition de seneste årtier er udviklet en række brobygningsteorier, der søger at skabe en syntese mellem struktur og aktør, har by- og boligforskningen stort set ikke formået at kombinere aktør- og strukturniveauet. Det er David Claphams grundlæggende pointe, og med sin bog The Meaning of Housing - A Pathway Approach leverer han sit bud på en tilgang, der vægter både de strukturelle forhold og mikroprocesserne i forståelsen og fortolkningen af menneskers bevægelser og placeringer på boligmarkedet. Clapham har et social konstruktivistisk afsæt, og hans grundlæggende ræsonnement er, at vi skal forstå både de samfundsmæssige og institutionelle forholds betydning for, hvordan mennesker vælger at bo, og vi skal undersøge de samfundsmæssige diskursers definitioner af fx familie, husholdning, hjemløshed og udsatte boligområder for at afdække, hvordan diskurser skaber rammerne for menneskers hverdagslivs og livsform. Samtidigt tillægger Clapham individerne en handlingsorienteret kapacitet til at påvirke og omforme de rammer, som sættes strukturelt og institutionelt. Individer vælger ikke frit, men er heller ikke udelukkende underlagt de samfundsmæssige rammer og begrænsninger.

Det centrale begreb, som Clapham indfører, er housing pathway, og det kan på dansk bedst oversættes til boligmønster. Clapham definerer housing pathway som:

as patterns of interaction (practices) concerning house and home, over time and space...the housing pathway of a household is the continually changing set of relationships and interactions that is experiences over time in its consumption of housing (27).

Med denne definition er housing pathway en videreudvikling af begrebet boligkarriere, hvor boligkarriere referer til et successivt forbrug af bolig, mens housing pathway eller boligmønster herudover lægger vægt på socialitetens og stedets betydning for valg af bolig. Heri er Claphams væsentligste bidrag til by- og boligforskningen, nemlig at vi skal inddrage individers livsverden og den betydning, de tillægger deres livsform, hjem og bolig i en forståelse af, hvorfor mennesker vælger at bo som de gør. Med andre ord handler boligvalg og boligkarriere ikke kun om rationelle beslutninger eller samfundsmæssige begrænsninger, men handler også om ideer, forventninger, visioner, ønsker og præferencer.

Anthony Giddens udgør en stor inspirationskilde for Clapham og måske næsten i et omfang, hvor det virker som om det er Giddens selv, der er åbenbaringen og ikke hans teori. Clapham henter inspiration i Giddens strukturations- 
teori og ide om sociale praktikker sammenholdt med tids- og rumdimensionen. Han diskuterer sporadisk betydningen af, at vi vælger vores identitet og livsstil i forhold til, hvordan vi indretter os boligmæssigt. Et tilbageblivende spørgsmål er dog, hvad Giddens' begrebsapparat egentlig bibringer i forhold til at inddrage individerne og deres livsverden i en forståelse af boligmønstre over tid. Clapham går aldrig rigtig ind $i$ at udfolde begreberne i boligmæssig kontekst, men henviser til, at begreberne har betydning, når vi vil forstå, hvad der motiverer os til at blive boende i et problemramt boligområde eller til at flytte. I samme skuffe omtaler Clapham også globalisering som en væsentlig betydningskilde for at forstå menneskers boligmønstre uden på noget tidspunkt at diskutere globalisering, og hvordan lokale forhold og globalisering egentlig spiller sammen.

Kapitlerne 1 og 9 består dels i at opstille den teoretiske ramme for at undersøge boligmønstre, dels i en diskussion af metodologiske krav til at gennemføre analyser, der afspejler, at boligmønstre er et resultat af de strukturelle, institutionelle og individuelle forhold. Begge kapitler indeholder gode og velovervejede ræsonnementer om samspillet mellem teori og empiri i by- og boligforskningen. I den sammenhæng kritiserer Clapham de store mængder af teoriløse undersøgelser, der gennemføres af boligforskere. En kritik, man ikke kan være uenig i, og som ikke kun kan rettes mod den angelsaksiske boligforskning, men også gør sig gældende i den skandinaviske boligforskning. Teori glimrer konstant ved sit fravær, hvilket er dybt problematisk for boligforskeres forståelse af det felt, de beskæftiger sig med.

Kapitlerne 2 til 6 indeholder gennemgange af den eksisterende boligforskning og er et forsøg på at fremstille kompleksiteten i at forstå menneskers boligmønstre. Clapham diskuterer, hvad en husholdning er og fremhæver, at husholdninger ændres over tid og rum i sammenhæng med ændrede familiestruk- turer. Clapham tager også fat i, at arbejdsmæssige karrierer overlapper med en persons/husholdnings karriere og boligmønstre, og at bolig og arbejde må analyseres i sammenhæng med hinanden. Ligeledes gennemgår Clapham, hvordan boligmarkedets finansiering sætter en institutionel ramme for vores boligmønstre, og hvordan ens boligområde - det sted man bor - har betydning for vores boligvalg og tilknytning.

Gennemgangen af forskningslitteraturen i kapitlerne 2 til 6 er grundig, læsbar og godt formidlet som introduktion for studerende og nye boligforskere. Men helt overordnet er gennemgangen og diskussionen køns-, seksualitets- og farveblind. Det svækker Claphams eget teoretiske afsæt og forsøg på at fremstille kompleksiteten, idet køn, seksualitet og etnicitet er væsentlige vektorer $\mathrm{i}$ menneskers indretning af deres liv. Derudover falder Clapham lidt hen ad vejen for sin egen kritik, fordi det faktisk lykkes ham i diskussionen af forskningslitteratur i forhold til at forstå kompleksiteten af folks boligmønstre at fjerne fokus fra individerne og forblive på et institutionelt og strukturelt niveau, hvor samspillet med aktørplanet aldrig helt kommer i spil. Betydningen af individers ønsker, præferencer og visioner for deres liv vægter Clapham stor set ikke i kapitlerne 2 til 6. Det svækker gevaldigt bogens ambitioner.

I kapitlerne 7 og 8 forsøger Clapham at anvende sin pathway tilgang til at forstå unges overgang fra at bo hjemme hos forældrene til at flytte i en bolig for sig selv og overgangen i ældres liv, hvor de flytter til en bolig, der bedre passer til dem i deres alderdom. Her viser Clapham anvendeligheden af sin tilgang om end med det forbehold, at aktørniveauet ikke i væsentlig grad kommer i spil i analyserne. Materien i form af præferencerne, motiverne, ønskerne og visionerne, som både de unge og de ældre har, bliver ikke inddraget $\mathrm{i}$ disse overgangsanalyser.

Samlet set leverer Clapham med sin bog et godt og gedigent indlæg i by- og 
boligforskningen og er et forsøg på at syntetisere aktør og struktur i analyserne af boligmarkedet og menneskers bevægelser på boligmarkedet. Samtidigt er det et tiltrængt teoretisk bidrag fra én af boligforskningens egne folk, hvor det ellers kniber med at give plads til teoretiske ræsonnementer, der kan kvalificere de empiriske analyser.

\section{Gunvor Christensen}

SFI - Det Nationale Forskningscenter for Velfærd

\section{Hans Thor Andersen:} Storbyens ændrede socialgeografi. Storkøbenhavn i et nordvesteuropæisk perspektiv.

København: Hans Reitzels Forlag, 2005 (275 sider)

Denne afhandling blev i 2005 forsvaret som en doktorafhandling i geografi ved Det naturvidenskabelige Fakultet, Københavns Universitet - vel primært fordi Hans Thor Andersen (HTA) er geograf. Den kunne dog formentlig også have været en sociologisk afhandling. Den handler nemlig i bund og grund om social ulighed, marginalisering, globalisering, velfærdsstat, politik og indflydelse, og den omstændighed, at den søger at belyse disse ting via deres geografiske udbredelse og i forhold til planlægningen og politikken i og omkring Danmarks hovedstad, burde ikke gøre den sociologiske interesse i emnet mindre - snarere tværtimod: Dels bliver tingene på den måde mere til "at tage og føle på", de kommer tættere på vores hverdag. Og dels er de sociale forholds rumlige udbredelse og fordeling en alt for overset faktor, og konsekvens, i sociologien.
Hans Thor Andersen viderefører her på bedste vis planlæggerfagets gamle tradition for tværfaglighed og kontekstorientering, hvad der er yderst frugtbart, når det som her handler om meget komplekse forhold. Fristelsen til alt for megen "smart" teoretisk og abstrakt forenkling af en sammensat empirisk virkelighed modstås ganske bevidst. Når nu verden faktisk er sådan indrettet, er vi ikke tjent med andet. På den anden side sker dette på bekostning af overskuelighed og "state of the art" hist og her, bl.a. også i forhold til sociologisk teori og metode, som skal være hovedperspektivet i det følgende.

Som titlen angiver, handler afhandlingen om storbyens, specielt Storkøbenhavns ændrede sociale geografi i et komparativt perspektiv (træk fra Stockholm, Oslo, Amsterdam, Rotterdam, Haag, Hamborg, Hannover og Frankfurt indgår som empirisk bagtæppe, og via den teoretiske diskussion involveres det meste af den vestlige verdens storbyudvikling i øvrigt, hvorved netop betydningen af forskellige politikker og velfærdsregimer kan isoleres). Men dette er selvfølgelig kun et overfladisk signalement.

Tidsperspektivet afgrænses, så nogenlunde, til perioden 1980-2000, med empirisk hovedvægt, for Danmarks vedkommende, på registerudtræk fra Danmarks Statistik 1988-1997 og enkelte data til og med 1999. Hermed søger HTA at fange den "nyorientering" der angiveligt er sket i overgangen fra det industrielle til det postindustrielle samfund mht. både byudvikling og velfærd (se nedenfor). I bredere forstand er det hensigten hermed at indfange konsekvenserne af (dele af) den såkaldte internationalisering, selvom det klart nok ikke er helt så let at afgrænse dette særlig præcist tidsmæssigt - hverken teoretisk eller empirisk eller med hensyn til indhold i øvrigt for den sags skyld.

Det geografiske perspektiv er ligeledes både klart og mindre klart bestemt: Hovedstadsområdet afgrænses ganske præcist til Københavns og Frederiks- 
bergs kommuner, alle kommuner i Københavns Amt samt seks kommuner fra Frederiksborg og to fra Roskilde Amt, i alt 28 kommuner. Helsingør, Hillerød, Frederikssund, Roskilde og Køge og deres umiddelbare oplande er således ikke med, for ikke at tale om resten af Sjælland og omliggende øer. Inden for det udpegede område opereres der derudover med 106 mindre byområder, der som enklaver er valgt som relevante "vinduer" til udviklingen på det mere detaljerede niveau - ud fra en statistikbase, som er stillet til rådighed af Hovedstadens Trafikselskab (det er ikke mindst via denne supplerende analyse på lokalniveau, at afhandlingen bidrager med afgørende nyt). I bredere geografisk forstand er der som sagt derudover "den nordvesteuropæiske komparationskontekst" og bag denne igen, via den teoretiske baggrundsdiskussion, den noget mere indefinite globale kontekst (også selvom HTA gør en del ud af at pointere, at det netop ikke er den generelle "globaliseringsdiskussion", men den mere afgrænsede europæiske integrationsproces, der er omdrejningspunktet). Også den rumlige afgrænsning refererer dermed til afhandlingens egentlige teoretisk-emnemæssige ærinde, og her er præciseringen knap så klar, dels på grund af "sagens natur" - den komplicerede og sammensatte problemstilling - og dels fordi der måske trods alt alligevel godt kunne have været trukket lidt flere streger i sandet?

Det overordnede forskningsspørgsmål er følgende (s. 11):

Har den nutidige storby, den postindustrielle by, som følge af den erhvervs- og velstandsmæssige udvikling, en anderledes socialgeografi end den hidtidige industriby?

Mere konkret handler det om at substantivere en række antagelser, der ikke altid formuleres særligt eksplicit og slet ikke som egentlige, sammenhængende hypoteser, om, at der i denne periode, reaktiveret af den europæiske integrationsproces og den heri indeholdte skærpelse af den nationale konkurrence, er sket en stigende social segregering både marginalisering og polarisering og at dette har givet sig udslag i, og spillet sammen med, en tilsvarende rumlig segregering, samt at der bag dette igen er en række handlinger og aktører involveret $i$ et samtidigt skift $i$ både planlægningspolitikken og velfærdspolitikken hhv. fra national geografisk udligning/ lighed til satsning på konkurrencen mellem de store europæiske byer/København (for Danmarks vedkommende) og fra velfærd som social lighed til velfærd via forbedret konkurrenceevne, med andre ord: fra gammeldags socialdemokratisk (velfærds-)politik med fokus på de svage (områder og borgere) til "moderne" neoliberal (erhvervs-)politik med fokus på de stærke (områder og borgere), altså det, vi i dag (2007) kalder "konkurrencesamfundets retorik". Som det formuleres af HTA (på side 67):

Byerne i Europa har som helhed fået en større plads på den politiske dagsorden og har forandret sig fra at udgøre koncentrationer af problemer til at være nationale styrkepositioner både i økonomisk og kulturel samt politisk forstand.

I denne udviklingsproces spiller både den eksisterende boligstruktur (infrastruktur og øvrige materielstruktur) samt bolig- og infrastrukturpolitikken en central rolle som både træg og formidlende faktor. Det hører også med, at de involverede aktører og deres ageren i det rumligt-sociale samspil angiveligt har været nedtonet og skjult bag den almindelige globaliseringsdiskurs på trods af disse forholds afgørende betydning i den nye transformationsdynamik. Derfor netop afhandlingens mål at afdække denne struktur-aktørsmæssige, materielle-sociale, rumligt-sociale og globaltlokale dialektik. Tilmed som alternativ til den ellers fremherskende forståelse 
af "globaliseringen" som et spørgsmål om en IT- og kommunikationsteknologi drevet af industrialiseringsprocessen mod et service-videnssamfund. Endelig lanceres undersøgelsen i høj grad som et både bredt og dybt (kvantitativt) empirisk orienteret og dokumenteret alternativ til de ofte alt for nemme og letfærdige teoretiske generaliseringer, som litteraturen på dette område ellers er så fuld af. Derfor også det omhyggelige metodiske design med sammenligning ud fra multiple cases, registerbaserede data på både regionalt, kommunalt og sub-kommunalt niveau, konstruktion af segregations- og ulighedsindex, sammenholdning af strukturelle dynamikker med konkret (planlægnings)politisk handlen og rollefordeling over tid, og i øvrigt gennemgående omhyggelig begrebsafgrænsning.

Lyder det kompliceret og ambitiøst? Så er det kun, fordi virkeligheden bare er sådan på dette område og derfor også må afspejle sig i et projekt, der for alvor sætter sig for at afdække dette. Lykkes det så? - eller snarere, fordi dette er en alt for unuanceret måde at spørge til dette komplekse forehavende på: Hvor langt når HTA med dette koncept og disse intentioner. I hvilken udstrækning er det konceptet og i hvilken udstrækning den konkrete indsats, det beror på?

Fra analysen af de europæiske storbyer konkluderes det forsigtigt, at gennemgangen:

har ikke umiddelbart kunne finde dokumentation for påstandene om markant voksende sociale forskelle eller segregation, som hævdet i polariseringsdebatten. I de fleste tilfælde er der tale om en høj grad af stabilitet i byernes socialgeografi - uagtet at der i samme periode kan iagttages en tydelig stigning med hensyn til ulighed i indkomstfordelingen, større variation i husstandssammensætningen og forøget indvandring.
En vis udvikling i den forventede retning kan dog konstateres mange steder, men når stabiliteten trods alt er fremherskende, tilskrives det først og fremmest boligmarkedets træghed: Det er kun de mobile og de nye ejere/lejere, der påvirkes, og som påvirker. Ting tager tid $\mathrm{i}$ denne branche.

Samme billede tegner sig i vidt omfang for Storkøbenhavns vedkommende - specielt når man anvender kommunerne som enhed. På en række områder, fx mht. arbejdsstilling, er der endda tale om en reduktion af segregeringen $i$ perioden, men som helhed må det siges, at ulighederne, specielt de sociale og de socio-spatiale, reproduceres og består. Indkomstfordelingen udviser dog en dobbelthed: På det kommunale niveau sker der en vis udligning: Det relative niveau i Københavns Kommune og i Vestegnen stiger lidt, mens det falder tilsvarende i Nordegnen. Samtidig kan der imidlertid iagttages en polarisering på områdeniveau, således at de rigeste enklaver bliver rigere, mens de fattigste bliver fattigere. Dette leder frem til den endelige og mere nuancerede konklusion: Under en tilsyneladende stabil og i visse henseender mere jævn overflade er der en ikke ubetydelig polariserende dynamik på områdeniveau båret af specielle grupper af befolkningen, som i høj grad peger fremad: Yngre voksne, enlige med børn og børnefamilier samt høj- og lavstatusgrupperne bliver fortsat mere ulige fordelt. Der sker så at sige en polarisering oppefra. De ressourcestærke vælger selv til og fra og gør derved en række (bolig)områder mere homogene, og ekstreme. Segregeringen er så at sige blevet nedskaleret fra det kommunale til det lokale niveau. Dette er nok væsentligt, men kan næppe betegnes som en ny, postindustriel, endsige globaliseret bystruktur, mener HTA. Globaliseringens effekt er altid afhængig af lokale forhold, og disse er, når vi snakker bystruktur, overordentligt træge.

Som helhed må afhandlingen betegnes som meget solid og sober, takket 
være den stærke empiriske forankring, flerdimensionaliteten og en udpræget uvilje til at kaste sig ud i teoretiske generaliseringer og spekulationer mod at begrænse sig til det, som lige nu og her kan dokumenteres med forhåndenværende statistik. Det sidste fremstår dog også som en ulempe: Fantasi og vovemod er ikke denne afhandlings stærke side. Det virker som om, at øvelsen med at skrive sig op mod de ofte alt for skråsikre og letbenede teoretikere har tvunget forfatteren i den modsatte grøft for faktisk er der en hel del indikationer og overvejelser undervejs, som med fordel kunne have fået mere luft under vingerne med henblik at pege fremad frem for bare at aflive andres "myter".

Fra sociologisk hold skal jeg afslutningsvis kommentere et par momenter, der måske ikke skal ses som absolutte indvendinger, da det nu ikke var en sociologisk afhandling, men snarere som fremadrettede forslag til en mere tværfaglig indsats på dette område.

I betragtning af, at HTA for mig at se deler både teoretisk og metodisk-empirisk orientering med Manuel Castells, og i virkeligheden kan siges at gennemføre en mere lokal dansk og vesteuropæisk parallel til dennes globalt orienterede projekt: The Information Age, er det bemærkelsesværdigt, at dette vigtige arbejde helt glimrer ved sit fravær i denne afhandling. Den meget generelle afvisning af den herskende globaliseringsdebat og "de sædvanlige" IT-forklaringer holder ikke i dette tilfælde, specielt ikke i betragtning af, at IT, kommunikationsteknologi og globalisering faktisk indgår adskillige steder i HTS's egen argumentation og diskussion. Som minimum fortjente det i hvert fald en ordentlige (mod)argumentation.

Chicagoskolen, specielt Robert Parks bidrag, afvises ligeledes relativt overfladisk og ud fra sekundærlitteratur som mekanisk og deterministisk, på trods af at Park har en mindst lige så nuanceret opfattelse af det socio-spatiale samspil som HTA selv, og på trods af, at chicagotraditionens byopfattelse empirisk viser sig stadig at være gangbar for de vesteuropæiske storbyer i dag, og endda også erkendes som sådan. Her kunne et lidt nøjere studium have bidraget til en mere nuanceret forståelse af den aktuelle områdebaserede segregationsproces.

Uligheds- eller rettere klasseproblematikken, der viser sig at være ret afgørende, og som også behandles adskillige steder via kommentarer til andres teoretiske arbejder, kunne godt have fortjent en mere samlet og opdateret diskussion, også i relation til "det globaliserede videnssamfund", så vi fx ikke skulle se indkomstuligheden analyseret under demografikapitlet og adskilt fra analysen af erhvervsfrekvens og arbejdsstilling i kapitlet om socio-økonomiske forhold.

Når "velfærd" og velfærdspolitik nu indgår centralt i problemstillingen på lige fod med bolig- og bypolitikken, havde det vel egentlig været rimeligt, hvis den side af sagen, og dens konsekvenser for udviklingen, også havde været med? Om ikke andet for at fastholde aktørerne over for strukturerne.

Det er positivt og frugtbart, at en stor del af analysen baseres på registerdata $i$ form af en serie tværsnitsbilleder af diverse kommuner og delområder. Mere produktivt og fremsynet ville det imidlertid have været, hvis registrene for alvor have været anvendt til det, de på vore breddegrader er helt alene om at kunne, nemlig at belyse forløb som mere eller mindre aggregerede personbevægelser over tid og sted - gerne suppleret med GIS-information. Så ville man for alvor kunne udpege hvor/hvem, dynamikken kommer fra og hvorfor (hvis ellers Danmarks Statistiks diskretionshensyn tillod det) - om det fx kun er fordi, de ressourcestærke flytter sig, om der evt. er en selvforstærkende område- eller ghetto/guldkyst-effekt, eller om andre forhold og persongrupper også gør sig gældende. Under alle omstændigheder må en sådan metodik indgå i kommende analyser af danske og skandinaviske forhold, som det allerede er sket $\mathrm{i}$ 
SBi's og Hans Skifter Andersens analyser af indvandrernes mere og mere "internt segregerede" bosætningsmønster, som synes at have positivt nyt i forhold til Rockwoolfondens tværsnitsanalyser.

Endelig, og måske mindst lige så afgørende, har afgrænsningen af Københavnsområdet været alt for restriktiv og begrænset i denne analyse - måske også en effekt af at holde sig til det sikre og kendte? Storbyen København har for længst - også i analyseperiodens 80'ere og 90'ere - bevæget sig ud over de 28 nærmeste kommuner. Ikke mindst det, der ligger og er skudt op uden for den trukne grænse, markerer de nye sociospatiale elementer i hovedstadens etablering som en europæisk storby - på godt og ondt - med alt hvad det omfatter af mere eller mindre tvunget pendling og mobilitet af geografisk og erhvervsmæssig karakter. Her finder vi både nye eliteenklaver og taberghettoer, både "havudsigten" mod Nord og Nord-vest og Låsby-Svendsens skrothuse helt mod Syd, begge som usynligt fremskudte metastaser af "København" - for ikke at tale om "koloniseringen" af Sydsverige, båndbydannelsen tværs over Fyn til Trekantsområdet med Storebæltsbroen osv. Denne dimension er desværre helt segregeret bort i denne analyse.

Det - og de andre ting - vil forhåbentlig indgå i fremtiden. Hans Thor Andersen er så vidt vides i gang med en række nyere undersøgelser. Forhåbentlig følger han interessen for det sociologiske op, eller sociologer tager mod den fremstrakte hånd til et frugtbart samarbejde på dette trods alt solide og inspirerende grundlag.

\section{Jens Tonboe}

Aalborg Universitet

Institut for Sociologi, Socialt Arbejde og Organisation
I da Wentzel Winther: Hjemlighed - kulturfænomenologiske studier.

København: Danmarks Pædagogiske forlag, 2006 (285 sider)

\section{På feltvandring i hjemligheden}

Hjemmet spreder sig. Det offentlige rum fyldes gennem reklamer med henvisninger til hjemmet, arbejdspladser vil være andet og mere end locus for arbejde, og ligeledes profileres institutioner som andet og mere end opbevaring af børn og ældre. Hjemmet er sammen med kulturen igen blevet betydningsmættede komponenter i en politisk værdikamp. Endelig er hjemmene gennem de sidste årtier blevet mål for stigende investeringer i form af ud- og ombygninger, stigende huslejer og et stadigt mere segregeret boligmarked. Der er med andre ord ingen tvivl om, at Ida Wentzel Winther har identificeret et aktuelt og vedkommende forskningsobjekt. Udfordringen er imidlertid, at der kan gå hjem i næsten al ting. Derfor indledes bogen med en vigtig indkredsning. Denne er såvel begrebsmæssig som metodisk. Et hus er ikke det samme som et hjem. Hjemmet rækker, hævdes det, langt ud over materialiteten og indbefatter (også) praktikker, ideer, forestillinger og relationer. Derfor introduceres kulturfænomenologien som bærende optik. Med denne er det ambitionen at "placere sig midt inde i et givent emne eller problem" og derfra åbne for forskellige tilgange.

Metodisk består den nævnte indkredsning dels af udvælgelsen af informanter og dels af indledningen af en såkaldt feltvandring. Angående informanterne argumenteres der overbevisende for at udvælge 24 10-11-årige børn, idet denne aldersgruppe fremstilles som "seismografer, der kan fortælle, hvordan de opfatter og gør hjem“. Børnene blev udstyret med hver deres engangskamera og bedt om at tage billeder af "hjem" og det "at føle sig hjemme". Resultatet er 350 fotografier, der er blevet anvendt som udgangspunkt for interviews med 
deres respektive fotografer. På baggrund heraf indleder Ida Wentzel Winther en feltvandring, som ikke blot organiserer tilgangen til den indsamlede empiri, men gennemføres helt ud i bogens overordnede struktur og opbygning. Tanken er i opposition til det klassiske antropologiske feltarbejde at sprænge feltbegrebets lokaliserede og snærende rammer til fordel for en nomadisk vandring i landskaber bestående af foreliggende og teoretiske felter. Derved, hævdes det, undgår forskeren at tage plads og deltage i en konkret lokalitet i en længere periode, for i stedet at fange det fluktuelle og mangestedslige.

Konkret betyder det for bogen, at facetter og felter prioriteres frem for $\mathrm{fx}$ en samlende optik eller et samlende begreb. Der tales om "at føle sig hjemme", "at hjemme den", "hjemmet som sted", "hjemmet som idé", ligesom der laves en modstilling mellem et "hjemmet" og et "hjemmet-2". Der udvikles og anvendes kartografier over hjemmet, og i bogens kapitel 3 med titlen Fundamentet leveres en grundig gennemgang af især fænomenologiske klassikere og analyser omhandlende hjem, sted, rum, byen, mobilitet, familien og som et originalt indslag husmoderen.

Alene variationen af temaer betyder, at de fleste læsere vil finde overraskelser og nye aspekter i bogen. Ligeledes fører behandlingen af billedmaterialet til fine observationer. Man opdager tv'et og sengen som vigtige objekter, der i Ida Wentzel Winthers analyser bringes forfriskende videre end trivielle ytringer om husalteret og sengen som hule.

Imidlertid må man spørge, hvilken status billederne gives: Deres billeder, siger forfatteren, er en fremstilling af, hvordan de gerne vil vise deres hjem, bestemte rum og sig selv i disse rum.

Analysen af hjemligheden hviler med andre ord på repræsentationer af hjem, nemlig tekster og billeder. Hvor indskrænket det antropologiske feltarbejde end måtte forekomme, kan det, at observere og deltage i hjem, praktikker hvor der "hjemmes" og hvor sådanne praktikker forhandles, generere hvis ikke en indsigt, så i hvert tilfælde en fornemmelse for hjem. Hjemlighed er således noget der kikkes på og snakkes om, ikke noget der er blevet besøgt eller deltaget $\mathrm{i}$, hvilket kan forekomme problematisk, når netop anskuelsen af hjem og hjemlighed som følelse og forhandlet praksis er en af bogens centrale pointer.

Heldigvis gør forfatteren en undtagelse i sin afvisning af deltager-observation (feltarbejdet). Hun inddrager i vid udstrækning sit eget hjem. Det gør hun flere steder overbevisende. Desværre undlader forfatteren at præsentere sit eget hjem som en forhandlet praksis. Det er nok en stemning og et fællesskab, men forhandlinger med børn og mand, som ville kunne udgøre perspektiverende eksempler på postulater udledt af interviews over billeder, lades ude af fortællingen. Ikke desto mindre er der mange gode observationer og analyser, ligesom den grundige og uddybende præsentation af litteratur er en gave til enhver, der ønsker at vide, hvad der rør sig inden for feltet hjem og hjemlighed.

\section{Mark Vacher}

Institut for Antropologi

Københavns Universitet

\section{Hans Skifter Andersen \& Torben Fridberg (red.): Den almene boligsektors rolle i samfundet: Hvad ved vi fra hidtidig forskning og undersøgelser?}

Hørshom: Statens Byggeforskningsinstitut, 2006 (side 19-34)

Som titlen antyder, er der tale om en "state of the art" publikation. Publikationen består af 6 forskellige artikler, der belyser forskellige sider af den almene 
boligsektor og dens rolle i samfundet og for boligmiljøet. Artiklerne handler om, hvorfor der er behov for en social boligsektor, dens rolle i boligforsyningen, hvordan kommunen bruger sektoren, dens rolle i forhold til lokalmiljøet, herunder integration og særlig etnisk integration og beboerdemokratiet.

Den boligsociale sektor har været et vigtigt middel i Danmark og Skandinavien til at sikre borgerne en rimelig bolig uanset økonomisk formåen. Selvom der de senere år har udviklet sig såkaldte "negative sociale spiraler" i dele af den almene boligsektor, kan det ikke skygge for, at netop denne sektor har givet en boligstandard til de fleste, som er unik i europæisk sammenhæng. Politisk har der gennem årene måske været fokuseret for meget på den fysiske og økonomiske side af boligsektoren frem for den sociale, men nogle af de problemer, som sektoren står med i dag, synes at skyldes eksterne kræfter frem for interne. Næsten alle beboere synes glade for deres bolig og bosted, men boligområderne er blevet ramt af nogle problemer undervejs. Dels har kommunerne koncentreret sociale problemer i nogle almennyttige områder. Dels har der ikke løbende været taget hånd om den fysiske nedslidning af boligerne og områderne. Dels har der ikke før begyndelsen af 1990'erne været en politisk erkendelse af, at der også måtte iværksættes sociale programmer i de belastede boligområder. Endelig har man i sektoren ikke været opmærksom på "generationsproblemet", dvs. det forhold at der flytter nye grupper ind med andre behov og forventninger end de første generationer.

Situationen ser i dag ud til at være: (1) Beboerarbejdet domineres af "de gam$\mathrm{le}^{\text {“ }}$ og nu hovedsagelig 24-timers beboere (pensionister), (2) der bor mange enlige forsørgere i sektoren og (3) i de større byer er der sket en koncentration af immigranter og beboere med "anden etnisk baggrund", som det så smukt hedder politisk. Det tyder på en manglende mobilitet i sektoren, og selv om afdelin- ger, der har indført "fleksible udlejningsregler" (43), har forøget mobiliteten, har der tilsyneladende ikke været den store politiske interesse for at stimulere denne via forskellige former for incitamenter.

Derimod er beboerrådgiverne blevet en central dimension i det boligsociale arbejde i mange boligafdelinger. De er finansieret af kommuner og boligselskaber, og de synes overalt at have stor indvirkning på integration, målrettede aktiviteter og trivsel (60). De har også været aktive i forhold til etnisk integration via f.eks. sprogkurser, aktiviteter for kvinder og indsats over for udsatte børn og unge. Det er interessant, at der her synes at være en tvedelt tænkning mellem "social integration", der er relateret til rådgivning og etablering af væresteder, cafeer og værksteder, og "etnisk integration", der handler om opkvalificering og møder med beboerne (79-80).

I andelsboligsektoren og i den almene boligsektor er beboerdemokratiet noget, der fremhæves som unikt. Her er man løbet ind i et generationsproblem, hvor det ser ud til, at det er de "gamle" beboere, der arbejder i bestyrelserne med de lange ofte tunge bolig- og socialpolitiske problemer, mens den nye, unge generation primært engagerer sig i enkeltspørgsmål. Det er også "de gamle mænd“, der er mest aktive, men kvinderne kommer på banen i enkeltspørgsmål. Der er således en tendens til, at beboerdemokratiet er ved at gå fra "en livsform" i boligområdet til at være en "formel styreform" baseret på et "sæt af regler og procedurer" og med beboere, der kun engagerer sig i spørgsmål der "berører dem individuelt" (84). Det gamle rationale med, at "øget indflydelse giver øget ansvarsfølelse og deltagelse" (89), bør således gentænkes.

Rapporten rummer et væld af empiriske analyser, man bliver klog af, men der er få "hvorfor og hvordan analyser". På trods af at det politiske felt og samfundet som sådan har meget brug for den slags analyser, som sektorforskningen kan bidrage med, er kritik ikke 
velset politisk i Danmark. Og det har det ikke været siden 1980'erne. Sektorforskningens formidling af problemer med politisk sprængkraft handler derfor om antydningens kunst, dvs. ikke at fremstille hvorfor, men at stille en lang række spørgsmål eller forskningsresultater, som dels problematiserer den politiske og offentlige forståelse af emnet og dels gennem disse peger på betimeligheden i en (politisk) afklaring på spørgsmålene. Nogle eksempler kunne være:

- Multietniske boligområder hindrer ikke integration (16), men hvad gør så? Hvad skulle det politiske proaktive svar være på dette?

- Vurderinger lyder, at de boligsociale problemer først reelt løses, når flere beboere kommer i arbejde (49), hvorfor er kommunerne og staten så ikke mere aktive på dette område? Hvordan kan kommunerne argumentere for, at de mangler ressourcer til en forebyggende indsats (52), hvis løsenet er arbejdsmarkedsintegration?

Rapporten viser, at det boligsociale arbejdes reelle problem er prioriteringen af det lokale. Selvom det længe har været erkendt, at et af de væsentligste problemer er den manglende samfundsintegration via arbejde og uddannelse, har der ikke været en samordnet indsats mellem boligområde, kommune og stat for at sikre overgangen fra at være et lokalt og boligområde problem til at blive et samfundsmæssigt arbejdsmarkedsproblem. Det antydes også i flere af artiklerne.

Samfundspolitisk er det et problem, at boligsociale indsatser er projektorienterede og ikke procesorienterede. Selv om man f.eks. politisk ved, at det tager mindst 10-15 år at vende en negativ social udvikling, så har kvarterløft, som fx urban-programmet i Aarhus eller andre tiltag, maksimalt en 5-7-årig tidshorisont. Hvorfor? Sektorforskningen fungerer på mange måder som "de svages stemme" i samfundet, og da er det ærgerligt, at der ikke er mere politisk gehør og brug af dens enorme vi- denskompetence til at udvikle en selvkritisk og proaktiv politik på området. Rapporten er også en dokumentation af, at problemstillingerne har været de samme de sidste 20-25 år og de politiske tænkemåder tilsvarende.

Statens Byggeforskningsinstitut har en betydelig formidlingsrolle omkring boligpolitik og dens konsekvenser her i landet, og publikationen er et led i denne formidling. Den synes primært at rette sig mod politikere, beboere og studenter/forskere med en ny eller begyndende interesse for boligsektoren. Publikationen viser også, at SBI besidder en empirisk og teoretisk viden om feltet, som er uovertruffen her i landet, så ethvert projekt eller politisk initiativ inden for feltet bør starte med et indblik i instituttets udredninger og rapporteringer.

John Pløger

Roskilde Universitetscenter 